\title{
Chemical Composition and Larvicidal Activity of the Essential Oils of Cordia leucomalloides and Cordia curassavica from the Northeast of Brazil
}

\author{
Renata P. Santos, ${ }^{a}$ Edson P. Nunes, ${ }^{b}$ Ronaldo F. Nascimento, ${ }^{c}$ Gilvandete Maria P. Santiago, ${ }_{*}^{d}$ Gustavo \\ Henrique A. Menezes, ${ }^{d}$ Edilberto R. Silveira ${ }^{a}$ and Otília Deusdênia L. Pessoa ${ }^{*, a}$ \\ ${ }^{a}$ Departamento de Química Orgânica e Inorgânica, Centro de Ciências, Universidade Federal do Ceará, \\ CP 12.200, 60021-970 Fortaleza-CE, Brazil \\ ${ }^{b}$ Herbário Prisco Bezerra, Departamento de Biologia, Centro de Ciências, Universidade Federal do Ceará, \\ 60451-970 Fortaleza-CE, Brazil \\ ${ }^{c}$ Departamento de Química Analítica e Físico-Química, Universidade Federal do Ceará, CP 12.110, \\ 60461-970 Fortaleza-CE, Brazil \\ ${ }^{d}$ Departamento de Farmácia, Universidade Federal do Ceará, 60430-370 Fortaleza-CE, Brazil
}

\begin{abstract}
Os óleos essenciais das folhas de Cordia leucomalloides e Cordia curassavica foram obtidos por hidrodestilação e suas composições químicas determinadas por uma combinação de CGEM e CG-DIC. Como resultado, vinte e três componentes foram identificados em ambos os óleos, representando 98,6 e 91,2\% da composição volátil. O óleo essencial de C. leucomalloides foi caracterizado por uma alta percentagem de sesquiterpenos $(90,6 \%)$, sendo $\delta$-cadineno $(17,4 \%),(E)$-cariofileno $(15,7 \%)$, biciclogermacreno $(12,5 \%)$ e germacreno D $(11,2 \%)$ os majoritários. Por outro lado, o óleo de C. curassavica mostrou proporções similares de monoterpenos $(47,3 \%)$ e sesquitepenos $(43,9 \%)$, entre os quais $\alpha$-pineno (20,5\%), $\beta$-pineno $(13,1 \%),(E)$-cariofileno $(12,4 \%)$ e biciclogermacreno $(13,8 \%)$ foram os compostos predominantes. O potencial larvicida dos dois óleos foi avaliado contra larvas no terceiro estágio do mosquito Aedes aegypti. Os resultados mostraram que ambos os óleos apresentaram atividade biológica significativa, particularmente o óleo essencial de C. leucomalloides, o qual foi capaz de matar 98,7\% das larvas numa concentração de 100 ppm.
\end{abstract}

The essential oils obtained from the leaves of Cordia leucomalloides and Cordia curassavica were obtained by hydrodistillation and their chemical compositions determined by a combination of GC-MS and GC-FID. Twenty-three components were tentatively identified in both oils representing 98.6 and $91.2 \%$ of the volatile content. The oil of C. leucomalloides was characterized by a large percentage of sesquiterpenes $(90.6 \%)$, being $\delta$-cadinene $(17.4 \%),(E)$ caryophyllene (15.7\%), bicyclogermacrene $(12.5 \%)$ and germacrene D $(11.2 \%)$ the major ones. On the other hand, the oil of $C$. curassavica showed similar proportions of monoterpenes $(47.3 \%)$ and sesquiterpenes (43.9\%) among which $\alpha$-pinene $(20.5 \%), \beta$-pinene $(13.1 \%),(E)$ caryophyllene $(12.4 \%)$ and bicyclogermacrene $(13.8 \%)$ were the predominant compounds. The larvicidal potential of the two oils were evaluated against the third-instar of Aedes aegypti larvae. The results showed that both oils exhibited significant activity, particularly the oil of $C$. leucomalloides which was able to kill $98.7 \%$ of the larvae in the concentration of $100 \mathrm{ppm}$.

Keywords: Cordia leucomalloides, Cordia curassavica, essential oil, larvicidal activity, terpenoids

\section{Introduction}

The pantropical genus Cordia, represented by shrubs and trees, is one of the major and most important genus of the

*e-mail: opessoa@ufc.br family Boraginaceae. ${ }^{1}$ Some of its species yield excellent wood naturally resistent to attack of several organisms, ${ }^{2,3}$ while others are widely used in traditional medicine in several parts of the world. ${ }^{4-6}$ Various phytochemical studies on Cordia species have been published, revealing a great number and diversity of secondary metabolites including triterpenes, ${ }^{4}$ 
flavonoids, ${ }^{7}$ sesquiterpenes, ${ }^{8}$ saponins, ${ }^{9}$ hydroquinones ${ }^{3}$ and quinones. ${ }^{10}$ Nevertheless, there are few studies published about the chemical composition of the essential oils of those plants. To the best of our knowledge, only the chemical composition of the essential oils of C. curassavica (Jack.) (syn.: C. verbenacea D.C.), ${ }^{111}$ C. nitida Vahl., ${ }^{12}$ C. trichotoma Vell. ${ }^{13}$ and $C$. globosa (Jacq.) H.B.K. ${ }^{14}$ have been described. The two later were recently subject of our studies, including their essential oils.

A literature survey revealed that the oil of $C$. leucomalloides has not been reported but C. curassavica has been the subject of several studies, probably due its etnobotanical value. ${ }^{1,5,6,15}$ C. curassavica is a medicinal plant with anti-inflammatory and antimicrobial properties. Indeed, artemetin, a flavonoid with anti-inflammatory activity $^{5}$ was isolated from the leaves and its essential oil has exhibited antimicrobial properties. ${ }^{12}$ In addition, naphthoquinones with antifungal and larvicidal activities have been isolated from the roots of this plant. ${ }^{6}$ As part of our research program on Cordia species native to Northeast of Brazil, ${ }^{8-10,13,14,16-18}$ the current paper describes the chemical composition of leaf oils of C. leucomalloides and $C$. curassavica, as well as their larvicidal effects against the mosquito Aedes aegypti, the vector of the yellow fewer and dengue.

\section{Results and Discussion}

The list of volatile components and the percentage composition of both oils are shown in Table 1. In the essential oil of C. leucomalloides twenty-three constituents were identified, which represent $98.6 \%$ of the total composition. The sesquiterpenoids constitute the dominant fraction (90.6\%), with (E)-caryophyllene (15.7\%), germacrene D (11.2\%), bicyclogermacrene (12.5\%) and $\delta$-cadinene (17.4\%) as the major ones. Likewise, twenty-three constituents were also identified for C. curassavica accouting for $91.2 \%$ of the oil composition. The percentage of monoterpenes (47.3\%) and sesquiterpenes (43.9\%) were approximately the same. $\alpha$-Pinene $(20.5 \%)$ and $\beta$-pinene $(13.1 \%)$ were the most significant constituents identified in the monoterpene fraction, while $(E)$-caryophyllene $(12.4 \%)$ and bicyclogermacrene (13.8\%) were the main sesquiterpenes.

Previous studies on leaf essential oil of $C$. curassavica, from the southeast region of Brazil, showed that the main compounds were $\alpha$-pinene $(29.7 \%)$ and $(E)$-caryophyllene $(25.3 \%)$. Other terpenoids were also found in significant amounts including allo-aromadendrene $(10.0 \%), \alpha-$ humulene (4.6\%), $\beta$-gurjunene (4.1\%), spathulenol (2.8\%) and bicyclogermacrene $(2.7 \%){ }^{6}$ On the other hand, in the oil of $C$. curassavica from Panama, the most prominent constituent was $\beta$-terpinene (32.0\%) followed by $(E)$ caryophyllene (12.0\%), camphene $(9.0 \%)$, germacrene D (9.0\%) and $\alpha$-pinene (6.0\%). ${ }^{1}$ Despite the compositional differences detected in the three oils samples of $C$. curassavica from different geographic sites it is important to emphasize the presence of $(E)$-caryophyllene and $\alpha$-pinene among the main constituents of both oils of Brazilian origin compared to the high content of $\beta$-terpinene solely for $C$. curassavica of Panamanian origin. $\alpha$-Pinene, (E)-caryophyllene, $\beta$-elemene, $\alpha$-humulene, bicyclogermacrene and $\delta$-cadinene are common constituents for $C$. curassavica of any origin, while camphene is common just to $C$. curassavica oils from Panama and Northeastern Brazil. It is also important to point out that $(E)$-caryophyllene, germacrene $\mathrm{D}$ and bicyclogermacrene are the major

Table 1. Volatile compounds identified in the leaf essential oils of $C$. leucomalloides and C. curassavica

\begin{tabular}{|c|c|c|c|}
\hline \multirow[b]{2}{*}{ Compounds $^{\mathrm{a}}$} & \multirow[b]{2}{*}{$\mathrm{KI}^{\mathrm{b}}$} & C. leucomalloides & C. curassavica \\
\hline & & \multicolumn{2}{|c|}{ Relative area / $(\%)$} \\
\hline$\alpha$-Phellandrene & 934 & - & 1.0 \\
\hline$\alpha$-Pinene & 942 & 1.5 & 20.5 \\
\hline Camphene & 953 & - & 0.8 \\
\hline Sabinene & 976 & 0.9 & 5.0 \\
\hline$\beta$-Pinene & 980 & 3.3 & 13.1 \\
\hline Myrcene & 992 & - & 0.9 \\
\hline$p$-Cymene & 1021 & - & 1.0 \\
\hline Limonene & 1031 & - & 1.5 \\
\hline$\gamma$-Terpinene & 1060 & - & 1.2 \\
\hline Linalol & 1096 & - & 1.1 \\
\hline Camphor & 1131 & 1.5 & 0.6 \\
\hline Borneol & 1163 & 0.8 & - \\
\hline 4-Terpineol & 1173 & - & 0.6 \\
\hline$\alpha$-Copaene & 1381 & 6.0 & 1.2 \\
\hline$\beta$-Bourbonene & 1388 & 0.8 & 0.9 \\
\hline$\beta$-Elemene & 1392 & - & 1.2 \\
\hline Longifolene & 1405 & 0.5 & - \\
\hline (E)-Caryophyllene & 1420 & 15.7 & 12.4 \\
\hline$\alpha$-Bergamotene & 1433 & - & 0.7 \\
\hline$\gamma$-Elemene & 1444 & 2.2 & - \\
\hline$\alpha$-Humulene & 1464 & 1.0 & 1.6 \\
\hline$\alpha$-Amorphene & 1484 & 2.1 & - \\
\hline Germacrene D & 1489 & 11.2 & 6.7 \\
\hline Bicyclogermacrene & 1503 & 12.5 & 13.8 \\
\hline Cubebol & 1515 & 1.1 & - \\
\hline$\delta$-Cadinene & 1525 & 17.4 & - \\
\hline Cadina-1,4-diene & 1532 & 0.6 & - \\
\hline Germacrene B & 1555 & 7.1 & - \\
\hline Spathulenol & 1565 & 3.2 & 2.2 \\
\hline Caryophyllene oxide & 1571 & 2.7 & 1.6 \\
\hline Globulol & 1574 & 1.8 & - \\
\hline Viridiflorol & 1590 & 1.5 & 1.6 \\
\hline$\alpha$-Bisabolol & 1652 & 3.2 & - \\
\hline Monoterpenes & & 8.0 & 47.3 \\
\hline Sesquiterpenes & & 90.6 & 43.9 \\
\hline Total & & 98.6 & 91.2 \\
\hline
\end{tabular}

${ }^{\mathrm{a} C o n s t i t u e n t s ~ l i s t e d ~ i n ~ o r d e r ~ o f ~ e l u t i o n ~ o n ~ D B-5 ~ c o l u m n . ~}{ }^{\mathrm{b}} \mathrm{KI}=$ kovats retention index according to $n$-alkanes. 
components common for oils from C. leucomalloides and C. curassavica from Northeast of Brazil, but $\delta$-cadinene for $C$. leucomalloides and $\alpha$ - and $\beta$-pinene for C. curassavica can distinguish them.

The leaf oils from both investigated Cordia species exhibited significant activity against the third-instar of A. aegypti larvae, showing $\mathrm{LC}_{50}$ of approximately 63.1 ppm for C. leucomalloides and of approximately 97.7 ppm for $C$. curassavica. The same order of $\mathrm{LC}_{50}$ have been observed previously for the essential oils from Lippia sidoides (63 ppm), Cymbopogon citratus (69 ppm), Ocimum americanum (67 ppm) and $O$. gratissimum (60 ppm) all considered of high interest for the control of $A$. aegypti. ${ }^{19,20}$ Taking in consideration the $\mathrm{LC}_{50}$ of the mentioned oils and the almost two fold higher toxicity of the oil from C. leucomalloides, relative to $C$. curassavica, it can be stated that the oil from the former has potential to become a promising natural agent to threat the mosquito life cycle, thus helping in the prevention of dengue fever.

\section{Experimental}

\section{Plant material}

The leaves of C. leucomalloides (No. 34725) and $C$. curassavica (No. 34715) were harvested during the flowering stages in January 2005, from Crato County, Ceará, Brazil. Voucher specimens have been deposited at the Herbário Prisco Bezerra (EAC) of the Departamento de Biologia, Universidade Federal do Ceará.

\section{Extraction of the essential oils}

The fresh leaves of $C$. leucomalloides (780 g) were subjected to hydrodistillation in a Clevenger-type apparatus for 2:00 hours to afford $0.07 \%$ of a pale yellow oil: $[\alpha]_{\mathrm{D}}^{20}-16^{\circ}\left(c=0.05, \mathrm{CHCl}_{3}\right), \eta^{25} 1.6705$. The same procedure were applied to fresh leaves of $C$. curassavica $(900 \mathrm{~g})$ to yield $0.13 \%$ of also a pale yellow oil: $[\alpha]_{\mathrm{D}}^{20}$ - 30 $\left(c=0.05, \mathrm{CHCl}_{3}\right) ; \eta^{25} 1.6633$. The yields $(\mathrm{m} / \mathrm{m})$ were calculated based on the fresh weight of the plant materials. The isolated oils, after drying over anhydrous sodium sulfate and filtered were stored in sealed glass vials and maintained under refrigeration before analysis.

\section{Chemical analysis}

$G C$-FID. The quantitative analysis was performed on a Shimadzu GC-17A gas chromatograph equipped with a flame ionization detector using a non-polar DB-5 fused silica capillary column $(30 \mathrm{~m} \times 0.25 \mathrm{~mm}$ i.d., $0.25 \mu \mathrm{m}$ film thickness). Hydrogen was used as carrier gas at a flow rate of $1 \mathrm{~mL} \mathrm{~min}{ }^{-1}$ and 30 psi inlet pressure; split ratio 1:30; the column temperature was programmed from $35^{\circ} \mathrm{C}$ to $180{ }^{\circ} \mathrm{C}$ at a rate of $4{ }^{\circ} \mathrm{C} \mathrm{min}-1$, then heated at a rate of $17{ }^{\circ} \mathrm{C} \mathrm{min}{ }^{-1}$ to $280{ }^{\circ} \mathrm{C}$ and held isothermal for 10 min; both injector temperature and detector temperature were $250{ }^{\circ} \mathrm{C}$.

$G C-M S$. The analysis was carried out on a HewlettPackard Model 5971 GC/MS using a non-polar DB-5 fused silica capillary column $(30 \mathrm{~m} \times 0.25 \mathrm{~mm}$ i.d., $0.25 \mathrm{~mm}$ film thickness); carrier gas helium, flow rate $1 \mathrm{~mL} \mathrm{~min}^{-1}$ and with split mode. The injector temperature and detector temperature were $250{ }^{\circ} \mathrm{C}$ and $200{ }^{\circ} \mathrm{C}$, respectively. The column temperature was programmed from $35^{\circ} \mathrm{C}$ to 180 ${ }^{\circ} \mathrm{C}$ at $4{ }^{\circ} \mathrm{C} \min ^{-1}$ and then $180{ }^{\circ} \mathrm{C}$ to $250{ }^{\circ} \mathrm{C}$ at $10^{\circ} \mathrm{C} \mathrm{min}^{-1}$. Mass spectra were recorded from $30-450 \mathrm{~m} / \mathrm{z}$. Individual components were identified by matching their $70 \mathrm{eV}$ mass spectra with those of the spectrometer data base using the Wiley L-built library and two other computer libraries MS searches using retention indices as a preselection routine, ${ }^{21,22}$ well as by visual comparison of the fragmentation pattern with those reported in the literature. $^{23,24}$

\section{Larvicidal bioassay}

Portions of essential oils (5 to $500 \mathrm{ppm}$ ) dissolved in $\mathrm{H}_{2} \mathrm{O}$ :DMSO $(98.5: 1.5)$ were placed in a beaker $(50$ mL). 50 instar III larvae of A. aegypti were delivered to each beaker. After 24 hours, at room temperature, the number of dead larvae was counted and the lethal percentage calculated. A control using DMSO and water was carried out in parallel. For each sample, three independent experiments were run. The bioassays were performed at Laboratório de Entomologia, Núcleo de Endemias da Secretaria de Saúde do Estado do Ceará, Brazil.

At the concentrations of 500 and 250 ppm there was $100 \%$ larvae mortality for both oils. At $100 \mathrm{ppm}$ the observed mortality was $98.7 \pm 0.9$ and $50.7 \pm 2.0$, while at $50 \mathrm{ppm}$ the figures were $9.3 \pm 1.2$ and $16.0 \pm 2.0$, for $C$. leucomalloides and $C$. curassavica, respectively. This made possible the calculation of the $\mathrm{LC}_{50}$ as $63.1 \pm 0.5$ and 97.7 \pm 1.0 , for C. leucomalloides and C. curassavica, respectively.

\section{Acknowledgments}

The authors thank the financial support provided by CAPES, CNPq, FINEP, FUNCAP and PRONEX. 


\section{Supplementary Information}

GC-MS chromatograms of the essential oils from leaves of $C$. leucomalloides and $C$. curassavica are available free of charge at http://jbcs.sbq.org.br, as PDF file.

\section{References}

1. Goméz, N. E.; Witte, L.; Hartmann, T.; J. Chem. Ecol. 1999, 25, 1007.

2. Manners, G. D.; Jurd, L.; J. Agric. Food Chem. 1977, 25, 726.

3. Manners, G. D.; J. Chem. Soc., Perkin Trans. I 1983, 39.

4. Kuroyanagi, M.; Seki, T.; Hayashi, T.; Nagashima, Y.; Kawahara, N.; Sekita, S.; Satake, M.; Chem. Pharm. Bull. 2001, 49, 954.

5. Sertié, J. A. A.; Basile, A. C.; Panizza, S.; Matida, A. K.; Zelnik, R.; Planta Med. 1990, 56, 36.

6. Ioset, J. R.; Marston, A.; Gupta, M. P.; Hostettmann, K.; Phytochemistry 2000, 53, 613.

7. Silva, S. A. S.; Rodrigues, M. S. L.; Agra, M. F.; da-Cunha, E. V. L.; Barbosa-Filho, J. M.; Silva, M. S.; Biochem. Syst. Ecol. 2004, 32, 359.

8. Menezes, J. E. S. A.; Machado, F. E. A.; Lemos, T. L. G.; Silveira, E. R.; Braz-Filho, R.; Pessoa, O. D. L.; Z. Naturforsch., C: J. Biosci. 2004, 59, 19.

9. Santos, R. P.; Viana, F. A.; Lemos, T. L. G.; Silveira, E. R.; Braz-Filho, R.; Pessoa, O. D. L.; Magn. Reson. Chem. 2003, 41,735 .

10. Menezes, J. E. S. A.; Lemos, T. L. G.; Pessoa, O. D. L.; BrazFilho, R.; Montenegro, R. C.; Wilke, D. V.; Costa-Lotufo, L. V.; Pessoa, C.; Moraes, M. O.; Silveira, E. R.; Planta Med. 2005, 71, 54 .

11. Carvalho Junior, P. M.; Rodrigues, R. F. O.; Sawaya, A. C. H. F.; Marques, M. O. M.; Shimizu, M. T.; J. Ethnopharmacol. 2004, 95, 297.
12. Pino, J. A.; Bello, A.; Urquiola, A.; Marbot, R.; J. Essent. Oil Res. 2002, 14, 118.

13. Menezes, J. E. S. A.; Lemos, T. L. G.; Silveira, E. R.; AndradeNeto, M.; Nascimento, R. F.; Pessoa, O. D. L.; Flavour Fragr. J. 2005, 20, 149.

14. Menezes, J. E. S. A.; Lemos, T. L. G.; Silveira, E. R.; Pessoa, O. D. L.; Santiago, G. M. P.; Nascimento, R. F.; J. Essent. Oil Res., in press.

15. Velde, V. V.; Lavie, D.; Zelnik, R.; Matida, A. K.; Panizza, S.; J. Chem. Soc., Perkin Trans. I 1982, 2697.

16. Menezes, J. E. S. A.; Lemos, T. L. G.; Silveira, E. R.; BrazFilho, R.; Pessoa, O. D. L.; J. Braz. Chem. Soc. 2001, 12, 787.

17. Santos, R. P.; Silveira, E. R.; Lemos, T. L. G.; Viana, F. A.; Braz-Filho, R.; Pessoa, O. D. L.; Magn. Reson. Chem. 2005, 43, 494.

18. Santos, R. P.; Lemos, T. L. G.; Pessoa, O. D. L.; Braz-Filho, R.; Rodrigues-Filho, E.; Viana, F. A.; Silveira, E. R.; J. Braz. Chem. Soc. 2005, 16, 662.

19. Carvalho, A. F. U.; Melo, V. M. M.; Craveiro, A. A.; Machado, M. I. L.; Bantim, M. B.; Rabelo, E. F.; Mem. Inst. Oswaldo Cruz 2003, 98, 569.

20. Cavalcanti, E. S. B.; Selene, M. M.; Lima, M. A. A.; Santana, E. W. P.; Mem. Inst. Oswaldo Cruz 2004, 99, 541.

21. Alencar, J. W.; Craveiro, A. A.; Matos, F. J.; J. Nat. Prod. 1984, $47,890$.

22. Alencar, J. W.; Craveiro, A. A.; Matos, F. J. A.; Machado, M. I. L.; Quim. Nova 1990, 13, 282.

23. Stenhagen, E.; Abrahamson, S.; McLafferty, F. W.; Registry of Mass Spectral Data Base, Government Printing Office: Washington DC, 1974.

24. Adams, R. P.; Identification of Essential Oil Components by Gas Chromatography/Quadrupole Mass Spectroscopy, Allured Publishing Corporation, Carol Stream: Illinois, USA, 2001.

Received: January 10, 2006

Published on the web: July 13, 2006 


\section{Chemical Composition and Larvicidal Activity of the Essential Oils of Cordia leucomalloides and Cordia curassavica from the Northeast of Brazil}

\section{Renata P. Santos, ${ }^{a}$ Edson P. Nunes, ${ }^{b}$ Ronaldo F. Nascimento, ${ }^{c}$ Gilvandete Maria P. Santiago, ${ }^{d}$ Gustavo Henrique A. Menezes, ${ }^{d}$ Edilberto R. Silveira ${ }^{a}$ and Otília Deusdênia L. Pessoa ${ }^{*, a}$}

${ }^{a}$ Departamento de Química Orgânica e Inorgânica, Centro de Ciências, Universidade Federal do Ceará, CP 12.200, 60021-970 Fortaleza-CE, Brazil

${ }^{b}$ Herbário Prisco Bezerra, Departamento de Biologia, Centro de Ciências, Universidade Federal do Ceará, 60451-970 Fortaleza-CE, Brazil

${ }^{c}$ Departamento de Química Analítica e Físico-Química, Universidade Federal do Ceará, CP 12.110, 60461-970 Fortaleza-CE, Brazil

${ }^{d}$ Departamento de Farmácia, Universidade Federal do Ceará, 60430-370 Fortaleza-CE, Brazil

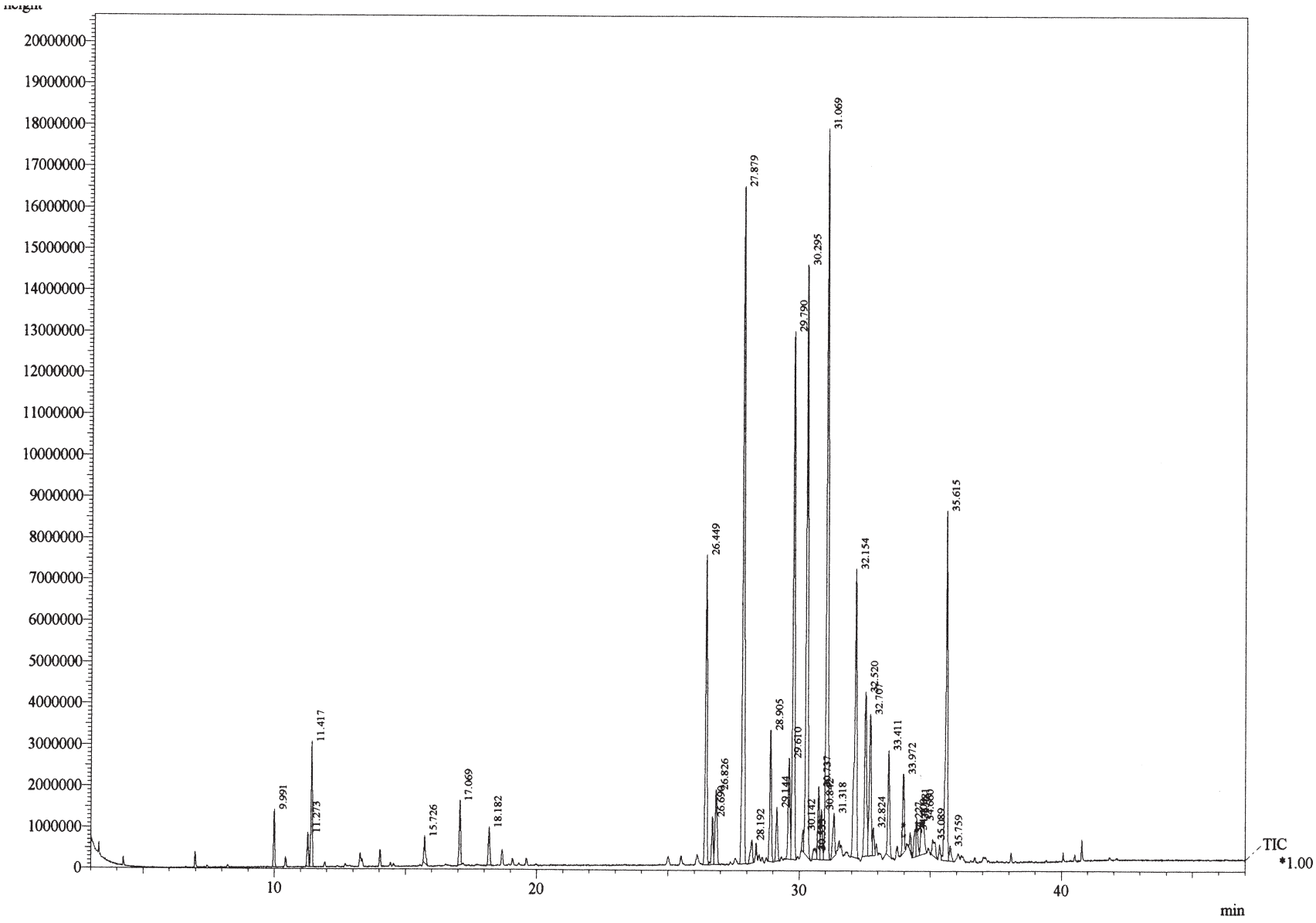

Figure S1. GC-MS chromatogram of the essential oil from leaves of Cordia leucomalloides. 


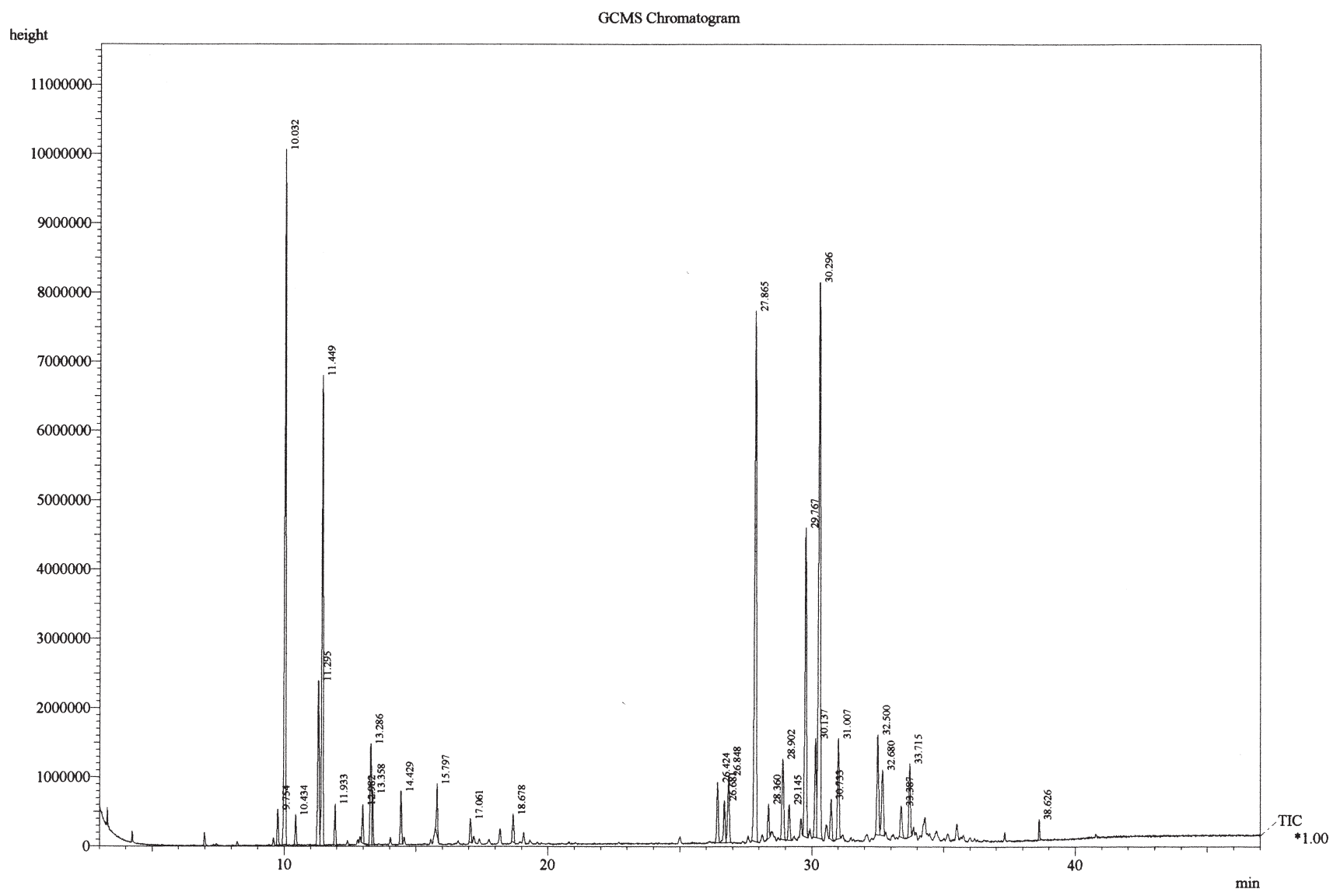

Figure S2. GC-MS chromatogram of the essential oil from leaves of Cordia curassavica. 